\title{
Crisis management, global challenges, and sustainable development from an Asian perspective
}

\author{
Yipeng Liu ${ }^{1,2} \cdot$ Fabian Jintae Froese ${ }^{3}$
}

Published online: 30 May 2020

(c) Springer Nature Limited 2020

\begin{abstract}
Research on crisis management has accumulated a vast body of knowledge that has assisted us with comprehending complex business and management phenomena. Yet, the existing studies have not paid sufficient attention to global challenges and sustainable development. We join the current conversation being conducted from the global challenges perspective of crisis management by suggesting that investigating global challenges and sustainable development can advance our collective understanding of crisis management in important ways. This article has three general objectives. First, we show that crisis management has been a long-standing issue in business and management research and provide an overview of the puzzles that informed and motivated this focussed issue. Second, we highlight the key insights and contributions made by the papers included in this focussed issue by reviewing their theoretical underpinnings, methodological approaches, and findings. Finally, we invite scholars to join the debate in order to move this important crisis management research agenda forward by tackling global challenges with the goal of achieving sustainable development.
\end{abstract}

Keywords Crisis management - Global challenges - Sustainable development · COVID-19 · Corona crisis · Asia

Yipeng Liu

yipeng.liu@henley.ac.uk

Fabian Jintae Froese

ffroese@uni-goettingen.de

1 Henley Business School, University of Reading, Reading, UK

2 Shanghai Institute of Technology, Shanghai, China

3 University of Goettingen, Goettingen, Germany 


\section{Crisis management from a multi-level and multidisciplinary perspective}

The 2020 COVID-19 global health crisis, the 2008 global financial crisis, the 1997 Asian financial crisis, and the list could go on. Nothing seems to be certain but death and crises. Accordingly, crisis management has been a long-standing issue in business management and organisational studies (Bundy et al. 2017). Over the past three decades, the three crises mentioned above have had major impacts on economic development and business evolution in Asia. The 1997 Asian financial crisis affected a wide region in East Asia and Southeast Asia and subsequently triggered fears of a worldwide economic meltdown. The 2008 financial crisis originating in Wall Street had a substantial and detrimental impact on the global economy, including Asian countries. In 2020, the unfolding of the COVID-19 global health crisis has been significantly reshaping business and management practices in Asian countries and beyond. Thus, understanding, managing, and intervening crisis is a critical challenge for all stakeholders involved. In order to capture the nuances of crisis management and organisational response, it can be useful to view crisis management from a multi-level and multidisciplinary perspective, including the individual, organisational, and institutional levels.

At the individual level, personal traits and emotional reactions can determine the extent of a crisis' effects. CEO empathy may help employees in making sense and finding meaning when faced by a crisis (König et al. 2020). The individual strategies adopted in coping with crises can be significantly influenced by cultural characteristics (Liu 2020), for instance, the influence of Confucianism prevailing in many Asian countries (Froese 2013; Xing et al. 2020). At the organisational level, organisational resources and capabilities can substantially determine whether organisations can survive dealing with a major crisis. Organisational learning and capability building are essential for organisations to learn, reflect upon, and accumulate lessons and experiences useful to handle the next crisis (Rerup 2009). In light of economic growth, rapid development, and previous crisis experience in Asian countries, organisational capabilities and crisis-handling abilities have been tediously honed and have remarkably improved over time. Asian countries have dealt with the COVID-19 global health crisis dramatically better than many of their Western counterparts, largely due to the experience accumulated during the 2003 SARS outbreak (Liu et al. 2020). At the institutional level, the varieties of Asian capitalism (Witt and Redding 2013) and institutional development can help the institutional infrastructure to be more resilient in absorbing any unprecedented but forthcoming crisis. Increasingly, cultivating appropriate crisis-coping strategies and building resilience is essential for individuals, organisations, and society to thrive in an age of uncertainties (Liu et al. 2019). Specifically, the juxtaposition of resilience research with crisis management (Williams et al. 2017) may offer revealing insights suited to solidify and improve business and management practices in Asian countries and beyond. 


\section{Global challenges and sustainable development}

In today's uncertain world, global challenges are becoming ever more complex and sophisticated, and necessitate a multidisciplinary and interdisciplinary approach. We believe that management research can and should make useful contributions to understanding and tackling global grand challenges (George et al. 2016) by addressing important questions (Tihanyi 2020). The United Nations envisaged 17 Sustainable Development Goals aimed at facilitating the achievement of sustainable development for mankind. For example, addressing sustainability challenges requires a collaborative approach in leveraging the power of entrepreneurship (Sarasvathy and Ramesh 2019). In the domain of international business, scholars urgently call for research to tackle 'big questions' and address 'grand challenges' in global business (Buckley et al. 2017). In a similar vein, we urge scholars in Asian contexts to step up and address the pressing global challenges faced by individuals, organisations, and society with good potential and value propositions suited to contribute novel insights in regard to both business practice and theoretical development.

A wide range of global challenges and associated research topics can be addressed in Asian contexts. Entrepreneurship and innovation activities are proactive and dynamic in Asia. The fast changing entrepreneurship landscape found in China and India continues to shape contemporary business and management practices and the future of both Asia and the world (Khanna 2008; Wu and Si 2018). Not only commercial entrepreneurship, but also hybrid entrepreneurshipincluding social, environmental, and institutional entrepreneurship - are taking place in Asian contexts in shaping the organisations and societies in which we live. Researching important challenges in Asian contexts may help to reveal novel business and management practices: for example, the reasons that, against expectations, caused Western internet digital giants to fail in the Chinese markets ( $\mathrm{Li}$ 2019), and the implications for innovation management for foreign companies operating in Asian contexts (Froese et al. 2019). As for the promotion and development of a greener economy, Asian countries, such as China, tend to deliver substance, rather than symbolic gestures, in reporting and implementing CSR initiatives (Marquis and Qian 2014). Furthermore, achieving sustainable development requires collaboration and partnerships that cross disciplinary boundaries. The importance of and interest elicited by Asian contexts notwithstanding, we believe that synergy can be generated and should be captured when scholars actively draw connections between Western and Eastern perspectives in management research (Filatotchev et al. 2020; Xing and Liu 2015) and theory development (Rhee 2010) for crisis management in particular, and for management and organisation theories in general. 


\section{A brief introduction to the papers in this focussed issue}

In this section, we will introduce the six papers in this focussed issue, which zoom in on different aspects of crisis management. We discuss the papers' theoretical underpinnings, methodological approaches, findings, and overall contributions to the study of crisis management, global challenges, and sustainable development. While the first four papers deal with the COVID-19 crisis, the remaining two centre on corporate crises in different contexts.

In the first paper, Liu et al. (2020) examine the business and economic implications of COVID-19 from an Asian perspective, focussing on the cases of China, South Korea, and Singapore. The authors take a novel approach by drawing from the theoretical underpinnings of entrepreneurship, agility, and resilience, which enables them to link the global health crisis to business and government responses. The novelty of the paper lies in the fact that it shows the impact COVID-19 is having on economies and businesses, the support provided by governments to businesses and societies, and the implications for global supply chain disruptions.

Following this seminal paper, three others delve deeper into the various business implications of COVID-19, covering human resource management, corporate governance, and supply chain management in different Asian contexts. Haak-Saheem (2020) discusses the consequences for talent management of the COVID-19 crisis by drawing from the case of Dubai, as the country's workforce is heavily reliant on expatriates. Yoshikawa and Chua (2020) explore the growing momentum of shareholder activism in Japan and articulate its relationship with the COVID-19 global health crisis, as well as the direction it could take post-COVID-19. Gao and Ren (2020) discuss the challenges to and opportunities for global value chains and the extent to which the current dependency on Asian countries may be reshaped in light of COVID-19 from the Australian and New Zealand perspectives.

In the fifth paper, Yang and Rhee (2020) show how public reactions to corporate bad deeds can influence CSR disclosure speed. By using a sample of 1023 boycott events targeting 93 firms in Korea between 2006 and 2016, the study contributes to the CSR literature by identifying the positive correlation between boycotts and CSR disclosure speed. Furthermore, the study shows that such correlation is moderated by business environment, suggesting that CSR disclosure is a risk-reduction mechanism against boycotts. Thus, the study highlights important contingencies and boundary conditions in examining CSR disclosure speed specifically, and the role played by sustainable development in crisis management in general.

In the sixth article, Lee and Zhong (2020) examine the way firms respond when their alliance partners misbehave. This study contributes to the broader crisis management literature by identifying the nuanced correlations that exist between responses to alliance partners' misbehaviours and firm performance as a function of the type of response strategy adopted. The paper's empirical setting includes Chinese equity-based alliances from 2001 to 2013, with a total sample of 
457 instances of misbehaviour. The results show that identity accommodation is associated with higher firm performance, while event defence is associated with lower firm performance. An important contribution made by the paper is in showing that the event-based view of alliance dynamics sheds new light on the ways in which firms manage uncertainty from partners and their effectiveness.

Collectively, these six papers effectively illustrate the wide scope of the topics of crisis management, global challenges, and sustainable development by including the COVID-19 global health crisis, talent management, shareholder activism, global value chain (in)dependence, CSR disclosure, and responses to alliance partners' misbehaviours. In conclusion, understanding the multifaceted aspects of crisis management through the global challenge and sustainable development perspectives can help us better understand and predict the antecedents, outcomes, and contingencies related to crisis management at multiple levels. We invite other scholars to join the debate to move forward this important and interesting research agenda.

\section{References}

Buckley, P. J., Doh, J. P., \& Benischke, M. H. (2017). Towards a renaissance in international business research? Big questions, grand challenges, and the future of IB scholarship. Journal of International Business Studies, 48(9), 1045-1064.

Bundy, J., Pfarrer, M. D., Short, C. E., \& Coombs, W. T. (2017). Crises and crisis management: Integration, interpretation, and research development. Journal of Management, 43(6), 1661-1692.

Filatotchev, I., Wei, L. Q., Sarala, R. M., Dick, P., \& Prescott, J. E. (2020). Connecting eastern and western perspectives on management: Translation of practices across organizations, institution and geographies. Journal of Management Studies, 57(1), 1-24.

Froese, F. J. (2013). Work values of the new generation of business leaders in Shanghai, Tokyo and Seoul. Asia Pacific Journal of Management, 30, 297-315.

Froese, F. J., Sutherland, D., Lee, J. Y., Liu, Y., \& Pan, Y. (2019). Challenges for foreign companies in China: Implications for research and practice. Asian Business \& Management, 18(4), 249-262.

Gao, H., \& Ren, M. (2020). Overreliance on China and dynamic balancing in the shift of global value chains in response to global pandemic COVID-19: An Australian and New Zealand perspective. Asian Business \& Management. https://doi.org/10.1057/s41291-020-00121-3.

George, G., Howard-Grenville, J., Joshi, A., \& Tihanyi, L. (2016). Understanding and tackling societal grand challenges through management research. Academy of Management Journal, 59(6), 1880-1895.

Haak-Saheem, W. (2020). Talent management in Covid-19 crisis: How Dubai manages and sustains its global talent pool. Asian Business \& Management. https://doi.org/10.1057/s41291-020-00120-4.

Khanna, T. (2008). Billions of entrepreneurs: How China and India are reshaping their futures-and yours. Boston: Harvard Business School Press.

König, A., Graf-Vlachy, L., Bundy, J., \& Little, L. M. (2020). A blessing and a curse: How CEOs' trait empathy affects their management of organizational crises. Academy of Management Review, 45(1), $130-153$.

Lee, L. S., \& Zhong, W. (2020). Responses to alliance partners' misbehavior and firm performance in China: The moderating roles of Guanxi orientation. Asian Business \& Management. https://doi. org/10.1057/s41291-019-00076-0.

Li, F. (2019). Why have all western internet firms (WIFs) failed in China? A phenomenon-based study. Academy of Management Discoveries, 5(1), 13-37.

Liu, Y. (2020). Contextualising risk and building resilience: Returnees versus local entrepreneurs in China. Applied Psychology: An International Review, 69(2), 415-443.

Liu, Y., Cooper, C. L., \& Tarba, S. Y. (2019). Resilience, wellbeing and HRM: A multidisciplinary perspective. The International Journal of Human Resource Management, 30(8), 1227-1238. 
Liu, Y., Lee, J. M., \& Lee, C. (2020). The challenges and opportunities of a global health crisis: The management and business implications of COVID-19 from an Asian perspective. Asian Business \& Management. https://doi.org/10.1057/s41291-020-00119-x.

Marquis, C., \& Qian, C. (2014). Corporate social responsibility reporting in China: Symbol or substance? Organization Science, 25(1), 127-148.

Rerup, C. (2009). Attentional triangulation: Learning from unexpected rare crises. Organization Science, 20(5), 876-893.

Rhee, M. (2010). The pursuit of shared wisdom in class: When classical Chinese thinkers meet James March. Academy of Management Learning \& Education, 9(2), 258-279.

Sarasvathy, S. D., \& Ramesh, A. (2019). An effectual model of collective action for addressing sustainability challenges. Academy of Management Perspectives, 33(4), 405-424.

Tihanyi, L. (2020). From "that's interesting" to "that's important". Academy of Management Journal, 63(2), 329-331.

Williams, T. A., Gruber, D. A., Sutcliffe, K. M., Shepherd, D. A., \& Zhao, E. Y. (2017). Organizational response to adversity: Fusing crisis management and resilience research streams. Academy of Management Annals, 11(2), 733-769.

Witt, M. A., \& Redding, G. (2013). Asian business systems: Institutional comparison, clusters and implications for varieties of capitalism and business systems theory. Socio-Economic Review, 11(2), 265-300.

Wu, J., \& Si, S. (2018). Poverty reduction through entrepreneurship: Incentives, social networks, and sustainability. Asian Business \& Management, 17, 243-259.

Xing, Y., Liu, Y., Tarba, S. Y., \& Wood, G. (2020). A cultural inquiry into ambidexterity in supervisor-subordinate relationship. The International Journal of Human Resource Management, 31(2), 203-231.

Xing, Y., \& Liu, Y. (2015). Poetry and leadership in light of ambiguity and logic of appropriateness. Management and Organization Review, 11(4), 763-793.

Yang, J., \& Rhee, J. H. (2020). CSR disclosure against boycotts: Evidence from Korea. Asian Business \& Management. https://doi.org/10.1057/s41291-019-00063-5.

Yoshikawa, T., \& Chua, G. (2020). COVID-19 and Japanese shareholder activism: Brief respite for Japan's self-healing concrete. Asian Business \& Management. https://doi.org/10.1057/s41291-02000122-2.

Publisher's Note Springer Nature remains neutral with regard to jurisdictional claims in published maps and institutional affiliations. 